\title{
PROBLEMS OF CANCER TREATMENT
}

\author{
PART 2 \\ TREATMENT BASED ON MODIFICATION OF ANTICANCER \\ IMMUNOLOGICAL RESPONSES IN THERAPY
}

Jerzy KAWIAK ${ }^{1}$, Grazyna HOSER ${ }^{2}$, Joanna DOMAGAŁA-KULAWIK ${ }^{3}$

${ }^{1}$ M.Nałęcz Institute of Biocybernetcics and Biomedical Engineering, PAN, Warsaw

${ }^{2}$ Laboratory of Cytometry, Medical Centre for Postgraduate Education, Warsaw

${ }^{3}$ Chair and Department of Internal Diseases, Pneumonology and Allergology, Warsaw Medical University

\section{DOI: $10.1515 /$ acb-2017-0007}

Summary: Here we present the concept of making own patient's anti-cancer treatment more efficient and starting at testing the efficacy of immunological system. The respective tests are suggested, with special attention devoted to tumour- induced microenvironmental changes. The tumour should be considered to represent a complex tissue in which the cancer cells communicate directly and indirectly with the surrounding cellular immunological surrounding and develope traits that promote their own survival. The results of tests allow to propose a rational, individually profiled treatment of a patient, especially directed to elimination of blocks inhibiting the immunological system due to effects of cancer cells. The elimination can be implemented using commercially available antibodies, targeted at the cell surface receptors for inhibitors of T lymphocytes (CTLA-4 and PD-1). Outcome of the therapy is slow to appear and the results used to be selective. Some patients gain long term improvement and respective predictive markers are now tested. It is assumed that the future anti-cancer therapy will be individually targeted, based on individual tests and an assistance of own immunological system of the cancer patient.

Keywords: immunotherapy, PD-1, CTLA-4 


\section{METHODS OF EVALUATING IMMUNE SYSTEM EFFICACY IN PATIENTS WITH TUMOURS}

An immunomodulating therapy represents a type of individualised therapy $[10,16]$. It is obvious that production of an autovaccine using tumour or leukemia antigens and own dendritic cells we refer to the well recognised condition of a given patient $[33,77]$. Nevertheless, with an increasingly broad introduction of immunotherapy with application of drugs, e.g. blocking local control of lymphocytes T (,checkpoints”), several problems appear linked to evaluation of immunity, defined as ,immunoscoring" [23]. Taking into account various responses to immunomodulatory treatment, the therapy, analogously to the targeted therapy should not be implemented without individual evaluation. Moreover, effects of immunotherapy may be unpredictable since it is a novel treatment and its distant effects remain unknown. In many patients the treatment releases severe undesirable effects, e.g. autoimmune reactions [67]. The following elements compose the problem of evaluating immunity in a patient with the tumour:

- evaluation of host's immunity on the basis of tests conducted on peripheral blood, - evaluation of immunity at the site of tumour development, e.g. in biopsy, surgical material, in BAL fluid,

- test of the biomarker significant in a prognostic evaluation is additionally used in clinical evaluation before therapy and can be monitored,

- the evaluation examines effects of the earlier applied chemo- or radiotherapy, target therapy and it should indicate potential for applying them in association with immunotherapy.

The environment within which solid tumour develops represents a distinct and specific space, housing cell mediated and humoral immunity interactions. The functional space of the microenvironment is formed by neoplastic cells, fibroblasts, cells of vascular endothelium, macrophages, dendritic cells, lymphocytes and the intercellular matrix. Moreover, tumour microenvironment manifests altered conditions, among other hypoxia, which promotes angiogenesis and modify epithelial-mesenchymal transition (EMT) of neoplastic cells [20].

A very important role in the immunosurveillance is played by cell-mediated defense. The tumour-surrounding inflammatory infiltrate contains variable numbers of inflammatory cells:

- tumour-infiltrating lymphocytes (TILs)

- tumour-associated macrophages (TAMs)

- tumour-associated neutrophils (TANs))

- tumour-associated tissue eosinophils (TATEs). 
A valuable material for evaluation of inflammatory reaction originates from the surgically removed tumour. In such a material a phenotype and function of TILs can be estimated. Since estimation of lymphocyte phenotype in the tissue material is very important, immunohistochemistry used to be employed. This, however, poses significant technical problems since due to the absence of applicable standardized methods of quantitative analysis, the results of such estimations are generally difficult to compare. In a few studies quantitative analysis of lymphocyte types which infiltrate the tumour was found to be useful as a prognostic index [42]. A similar significance is linked to typing of lymphocytes in lymph nodes, which were removed together with the tumour (surgery of, e.g. lung tumour, colorectal cancer, mammary tumour involves removal of the tumour with the margin of healthy tissues together with regional lymph nodes). Photograph 1 illustrates results of phenotyping of lymphocytes in lymph nodes excised from mediastinum together with lung cancer).

At present, clinical practice contains no standards for evaluation of body's immune system before implementation of the treatment. In view of introduction to therapy of drugs blocking PD-1/PD-L1 axis, in numerous studies expression of PDL1 was examined on cancer cells in archival surgical material. Immunohistochemical techniques and various techniques of quantitative evaluation were applied for the purpose. A review of such studies pointed to a relatively low proportion of PDL1 positive tumours (around 30\%), but also an extensive divergence of the results (13-80\%) [38]. Patients with presence of PD-L1 were found to survive longer than patients with the negative result $[25,76]$, even if the latter patients better responded to treatment. Therefore, credibility of several such studies is subjected to doubts. The question also arises whether presence of lymphocyte infiltrates in a tumour reflects the initial condition of a patient or (and to which extent) it has resulted from treatment (neoadjuvant chemotherapy). Results of studies on cells propagating the tumour seem to indicate the new sensible direction of studies: a pronounced expression of PD-L1 was demonstrated on cells of head and neck cancers; possibly they can be significantly responsible for mobilization of the mechanisms which reduce cytotoxicity of lymphocytes T [54]. It should be remembered that PD-L1 becomes expressed not only on cancer cells but also on lymphoid and myeloid cells and the appropriate therapeutic conclusions can be drawn only when distinction is made between the populations. In the context of the observed efficacy of the already registered drugs, blocking the so called checkpoints of T lymphocytes (CTLA-4, PD-1), evaluation of neoplastic cells in respect to expression of the ligands seems to represent an appropriate manner of qualifying patients with pulmonary carcinoma to immunotherapy. 

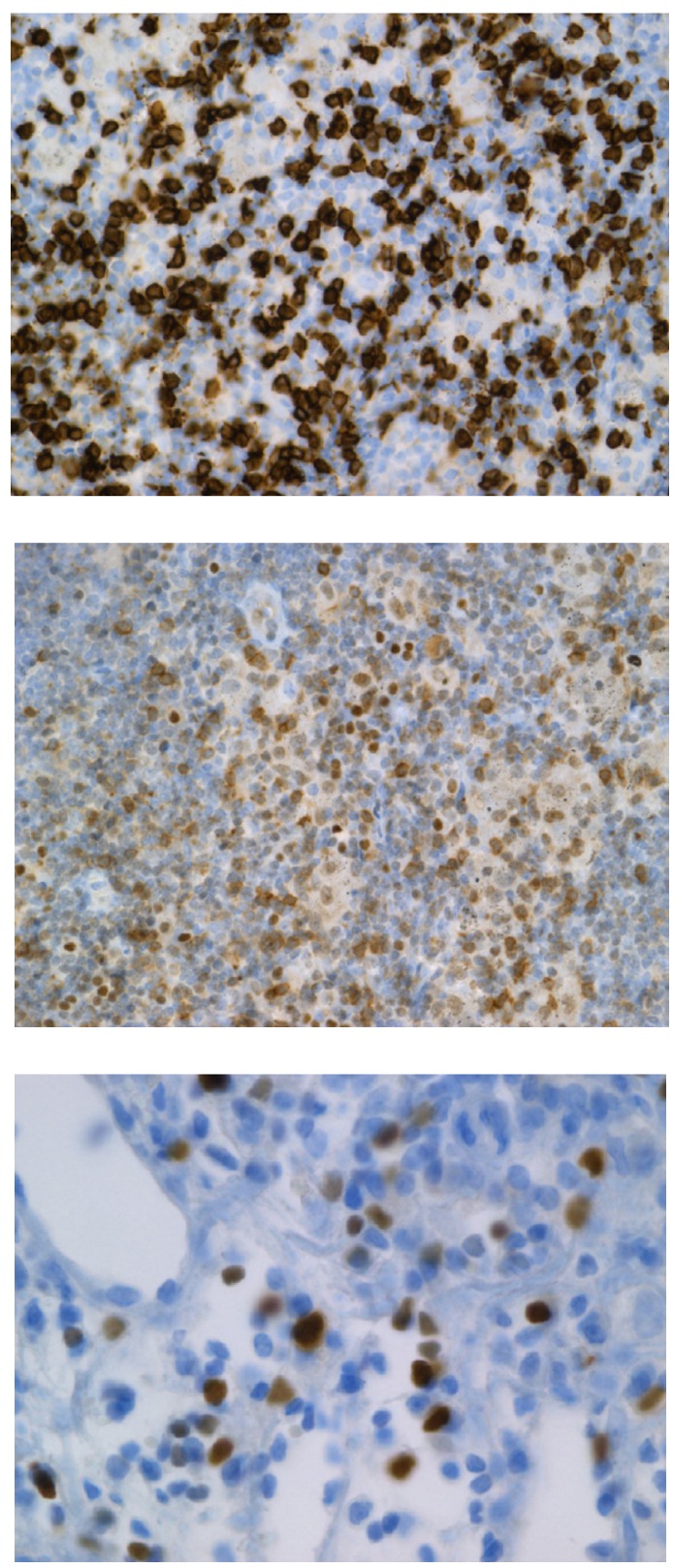

PHOTOGRAPH 1. Results of phenotyping of mediastinal lymph nodes resected in patient with lung adenocarcinoma. Monoclonal antibodies and automated immunohistochemical system (Systems/Roche Diagnostics Ltd.). Magnification x 400

a/ lmphocytes $\mathrm{T}$ CD8+, b/ lymphocytes CD25+, c/ lymphocytes with positive nuclear reaction for FoxP3 


\section{ANALYSIS OF IMMUNE SYSTEM CELLS IN LUNG CARCINOMA}

In most of cases, lung carcinoma (over 70\%) cannot be qualified for resection due to marked advancement of the disease at the moment of diagnosis and this restricts the potential for studies on the inflammatory infiltrate. Examination of small samples of tumour obtained upon diagnostic bronchoscopy provides no insight into the type of inflammatory infiltrate. Literature of the subject presents data obtained on cell lines developed from cells of lung carcinoma [69] or in experimental studies on animals. Most of studies analyzing immune system in patients with pulmonary were based on tests conducted on peripheral blood.

The method which allows to reproducibly and effectively evaluate type of inflammatory reaction at the site of lung cancer development involves bronchoalveolar lavage (BAL) [50]. BAL can be performed in patients with various and practically any stages of disease advancement. Moreover, it involves material sampled during routine diagnostic bronchoscopy, and it reflects the initial condition of immune system, before treatment and individually characterizing a given patient. The examination allows to obtain cellular and extracellular material from the bronchoalveolar space, from a significant surface of peripheral respiratory tract [2, 5]. In practice, this involves introduction of around $200 \mathrm{ml}$ of saline to the space of pulmonary alveoli, in samples of $50 \mathrm{ml}$ each, and sucking off the fluid until around $50-70 \%$ of the original volume has been recovered. The "rinsing of pulmonary alveolar surface" yields cellular suspension with few millions of cells manifesting the viability of over $90 \%$. In healthy non-smokers the cellular composition of BAL is constant: the suspension contains $>80 \%$ alveolar macrophages, $<20 \%$ lymphocytes, $<3 \%$ neutrophils and $<0.5 \%$ eosinophils [2, 5]. A routine processing of the material involves preparation of cell sediment, scoring the total number of cells, determination of types of the present cells, including, e.g., neoplastic cells and calculation of the proportion of inflammatory cells $[2,5]$. The obtained cell suspension can be qualified to examine cell phenotypes and cytokine composition using, i.a. flow cytometry, one of the principal approaches in evaluation of immune disturbances. The cells obtained in BAL can be isolated and cultured. In numerous studies, including our own, significance of BAL was proven in diagnosis of peripheral pulmonary tumours both in the range of cell analysis and produced by them cytokines $[7,11,13,14]$. A study conducted at present by the authors points to a distinct character of inflammatory reaction in the lung, which contains the tumour than in the lung containing no tumour. Thus, the immune diagnosis is justified in the region of pulmonary lobe containing the tumour.

Condition of the immune system is modified by external conditions, coexisting diseases and the applied drugs. A pronounced immunomodulatory effect of tobacco smoke has been proven: it affects not only the respiratory system but it also induces systemic alterations $[8,9]$. In our own studies we found a significant effect of 
tobacco smoking on lesions in pulmonary environment: in BALs obtained from smokers a proportion of helper Th lymphocytes $\left(\mathrm{CD}^{+}\right)$was reduced and that of cytotoxic Tc lymphocytes $\left(\mathrm{CD}^{+}\right)$was increased. This resulted in a marked reduction of the ratio of $\mathrm{CD} 4^{+}$to $\mathrm{CD} 8^{+}$lymphocytes. The ratio is commonly used in evaluation of cell-mediated immunity [30,31]. As already mentioned above, an inflammatory process in the respiratory system is markedly affected by coexisting diseases, particularly the chronic obstructuve pulmonary disease (COPD), also strictly linked to tobacco smoking. COPD augments the risk of developing lung cancer [73], it is an inflammatory disease and its development is supposed to involve effects of autoimmunity [12]. Inflammation in COPD is characterized by prevalence of $\mathrm{CD} 8^{+}$lymphocytes, neutrophils, proinflammatory cytokines and a deficiency of regulatory lymphocytes [12]. Analysis involving the condition of immune system in patients with pulmonary carcinoma one must take into account history of cigarette smoking and potential diagnosis of COPD [15] .

Examination of the induced sputum represents a certain equivalent of BAL in evaluation of inflammatory process in respiratory pathways [6]. This material originates from upper portions of respiratory system and, similarly to BAL, contains all the typical inflammatory cells, mostly macrophages and neutrophils. Unfortunately, such a material poorly qualifies for evaluation of lymphocyte subpopulations, but studies on macrophages with the use of immunocytochemistry yielded very interesting results. In our own studies we demonstrated that smoking of cigarettes induced an increased expression of activation markers on macrophages in the induced sputum, which may find application in early diagnosis of pulmonary cancer [28].

\section{DESCRIPTION OF PRINCIPLES IN TUMOUR TREATMENT, TAKING INTO ACCOUNT BLOCKING OF IMMUNE SYSTEM}

Description of the complete procedure in anti-neoplastic treatment may be summed up by:

a. maximum reduction of neoplastic cells number associated with possibly insignificant damage tonormal tissues (chemotherapy, radiotherapy, immunotherapy). b. expansion of the pool of lymphocyte clones able to recognise the neoplastic cells (vaccines) [80]

c. „unblocking” of the immune system by administration of anti-CTLA-4 and antiPD-1 antibodies (drugs)

d. „unblocking”of p53 protein finction, the inner pathway of apoptosis [26].

At the second stage of the treatment or in parallel the physician attempts to recover activity of the immune system, blocked in the neoplastic disease. Since the number of cells in the immune system, which are directed against the tumour 
remains unknown, the physician at first attempts to induce in the patient several clones of specific $\mathrm{T}$ lymphocytes recognising epitopes currently characterising the neoplastic cells [80]. The immune system can be activated using low doses of chemotherapeutic agents, e.g. cyclophosphamide restores homeostasis of dendritic cells [46]. Attempts are also made to activate inborn immunity using such agents as TLR agonists [62], or vaccination with dendritic cells „loaded” with antigens isolated from patient's tumour [34,63]. This, in a restricted range, is used in the treatment $[39,60]$. However, another approach to the problem is possible: tumour cells, similarly to normal cells may die due to apoptosis. Administration to the patient of cells of his own antigens, in the form of extracts, tumour lysates, viable cells with induced apoptosis may provide autovaccine and it provides the patient with objective clinical responses more frequently (in $8.1 \%$ of the patients ) in various tumours than in patients following therapy employing individual tumour antigens (a response in 3.6\% patients) [47]. Administration of autovaccine leads to presentation to lymphocytes $\mathrm{T}$ of the current tumour cell epitopes; current since a neoplastic tumour consists of various pathologically altered cells and the scope of their antigens alters during tumour development. Thus, autovaccine induces appearance in the host of multiple clones of $\mathrm{T}$ lymphocytes capable of recognising current epitopes of his own tumour. Such autovaccine was tested in an experiment on animals, in which mice were grafted with semisyngeneic leukaemic calls in apoptosis $[35,36,70]$. In optimal conditions of the experiment the tumours could be cured in even $2 / 3$ of the animals [36]. However, the animals manifested an efficient immune system. This differs from the patients in whom the developing tumour gradually makes the system inefficient. In a clinical experiment, similarly the autovaccine was administered to patients with chronic B-cell leukaemia $[33,37]$. This resulted in minimum unfavourable signs/symptoms but in some vaccinated patients it blocked increase in circulating numbers of leukaemic cells or resulted in their reduction during observation. In the patients the number and behaviour of various fractions of B, T, NK, Treg and NKT lymphocytes were controlled using flow cytometry. The vaccination resulted in a transient inhibition of the tumour development but it did not result in cure of the disease. In 10/17 patients, who responded to the treatment, the stable condition persisted for 45.6 months (3.8 years) (the observation was not longer continued before publishing of the results). In the paper published in parallel, the mechanism of neoplastic antigens cross-presentation by $\mathrm{mDC}$ cells was presented in similar patients [34]. In this procedure, production in vitro of myeloid auto- or allogeneic dendritic cells was described. The isolated dendritic cells were exposed in a culture medium to lysed or apoptotic leukaemic cells of the patient. The mDC cells phagocytosed the administered to the culture fragments and lysates of the cells. Such „burdened” dendritic cells, additionally activated in vitro by tumour necrosis factor (TNF $\alpha)$ were subcutaneously returned to the patient. This provided a type of vaccine. 
According to other authors [75], similar dendritic cells with the phagocytosed material become transplaced to lymph nodes [56] and there they cross-present, with MHC class I molecules, epitopes of leukaemic cells. In this case, the observed therapeutic effect resembled that noted following administration of autovaccine of in vitro irradiated leukaemic cells $[33,37,47]$. Also administration of dendritic cells was suggested as an anti-neoplastic vaccine [34,53], the effect of which might be amplified by low doses of chemotherapeutic drugs [59]. Obviously, financial cost and complexity of an experiement with in vitro production and use of dendritic cells do not permit to treat this approach as a routine method. Neverthelss, the data obtained in the clinical experiment supplement each other and administration of own irradiated leukaemic cells can be accepted to represent an examined on patients manner of augmenting clones of anti-neoplastic lymphocytes, the cytotoxic functions of which may be used.

The additional observation is worth noting, made on irradiated cells (unpublished data, Kawiak J, Tabarkiewicz J): apoptosis of leukaemic cells was induced using a dose of $1000 \mathrm{~Gy}$ gamma rays $\left({ }^{137} \mathrm{Cs}\right)$. Not all irradiated cells were found to immediately enter apoptosis, which, after its start, continued for around 2 hours. Some irradiated cells entered the process after one or even after 4 days and in this way extended the proapoptogenic action of a single cell irradiation and, therefore, also induction of anti-neoplastic lymphocytes activation following administration of the cells in the vaccine. Moreover, such cells with the induced but not yet started apoptotic process were described to release numerous microvesicles, very effective in transmitting neoplastic epitopes to lymphocytes $\mathrm{T}$ in the cross-presentation. Also at present the principle of administering vaccine of the own patient's neoplastic cells is followed since it represents a simple, economic and effective manner of the direct administration of antigens directly linked to the tumour, e.g. in AML. [61].

Already in the first part of this article the activated lymphocytes $\mathrm{T}$ were mentioned to be capable of an effective response when they received two signals: the signal of epitope recognition and the signal of co-stimulation. The latter originates from interaction of $\mathrm{CD} 28$ receptor on lymphocytes $\mathrm{T}$ with $\mathrm{B} 7$ ligands on the target cell and the interaction is blocked e.g. by CTLA-4 in tumours, including B-CLL cells [22]. Expression of CTLA-4 in cells of neoplastic tumours of, e.g. non-small-cell lung cancer (NSCLC) develops in 51-87\% cases [64]. CTLA-4, interacting with B7 of APC cells provides the signal for inhibition of immune response. Recovery of co-stimulation in cases of neoplastic process, i.e. recovery of the desirable reaction, would require blocking of CTLA-4. Such blocking humanised monoclonal antibody (Ipilimumab), binding to CTLA-4, undergoes at present clinical tests $[55,57]$ (tab. 1). 
TABLE 1. Antibodies used in clinical practice for unblocking immune system cells in malignancy

\begin{tabular}{c|c|c|c}
\hline ANTIBODY & ANTIGEN & TARGET CELLS & REFERENCES \\
\hline Ipilimumab & CTLA4 & Lymphocytes T & $63,64,65,45$ \\
\hline Nivolumab & PD-1 & Lymphocytes T & $1 \mathrm{a}, 75 \mathrm{a}$ \\
\hline Lambrolizumab & PD-1 & Lymphocytes T & 51 \\
\hline
\end{tabular}

Administration of anti- CTLA-4 antibody to a patient with a tumour, e.g. melanoma: a/ prevents against binding of CTLA-4 to B7 ligand on the antigenpresenting cell, $\mathrm{b} /$ reduces inhibition of CD28/B7 interaction following activation of lymphocyte $\mathrm{T}$, c/reduces numerical force of Treg lymphocyte population, which manifests persistant expression of CTLA-4. Administration of the antibody specific for CTLA-4 leads to activation of immune responses to neoplastic antigens in $40 \%$ patients with an advanced tumour, which cannot be surgically excised [71]. With a delay of a few weeks, positive effect of treatment with the antibody is noted in around $10 \%$ patients with NSCLC [72].

Neoplastic cells may express the PD-L1 ligand (CD274) (ligand of proapoptotic surface receptors of cell death), which in activated lymphocytes with expression of PD-1 receptor inhibits proliferation and induction of apoptosis. Expression of PD-1 is manifested by lymphocytes $\mathrm{B}$, lymphocytes NK and lymphocytes T. Ligands PD1, e.g. ligand PD-L1 are present on haemopoetic cells (lymphocytes B, T, myeloid and dendritic cells) but also on endothelial cells, cells in the heart, lungs, pancreas, muscles and placenta. On normal cells expression of the ligand is low. On the other hand, cells of neoplastic tumours exhibit high expression of PD-L1. Level of the expression was found to correlate with the survival of the patients. In patients with PD-L1-positive melanoma, expression of the ligand is higher locally, in the tumour environment with accumulated lymphocytes $\mathrm{T}$ [74]. The PD-L1 ${ }^{+}$melanoma cells were located close to TILs. Also INF $\gamma$ was detected in sites of contact between cells of melanoma PD-L1 ${ }^{+}$and TILs.

In many other neoplastic tumours TILs exhibit high expression of PD-1, and tumour cells manifest high expression of PD-L1 ligand [1]. Lymphocytes, monocytes and other cells gain manifestation of the receptors after activation. In this way, functions of tumour-recognising lymphocytes $T$ become eliminated by neoplastic cells. This can be prevented by administration of a specific anti-PD-1 antibody, the trade name of Nivolumab, currently registered for clinical trials in USA and Japan [68]. The antibody blocks binding site of PD-L1 ligand, which cannot reach PD-1 receptors on the recognising lymphocytes. In this way the latter are protected from apoptosis but the co-stimulation signal does not become unblocked. 
Nivolumab, the human monoclonal antibody of IgG4 class, free of ADCC cytotoxicity, was administered to patients with various tumours in their advanced stages, every two weeks for a period of two years. In an advanced melanoma, 1 and 2 years were survived by, respectively, 52\% and $43 \%$ treated patients [24] . Expression of PD-L1 ligand was evaluated also in the archival material of tumours and it was detected in $16 \%$ patients. A similarly targeted monoclonal antibody (Lambrolizumab) manifested a significant anti-neoplastic activity in melanomas [27]. Also another monoclonal antibody was produced, the tecomotid, directed against MUC1 antigen [4], the antibody with which hopes are linked related, in particular, to treatment of lung cancer. Clinical trals with the antibody blocking the PD-1/PD-L1 pathway demonstrated a sufficient efficacy in treatment of lung cancer that the drug was registered in USA and Europe for treatment of squamocellular cancer of the organ [57]. In a few studies presentation of augmented expression of ligands for PD-1 receptor by lung cancer cells was found to carry predictive significance: a better response is expected to treatment with anti-PD-1, anti-PD-L1 [66].

During in vivo attempts with the mentioned antibodies, the best results of treatment of melanoma and other examined tumours proved to be obtained using parallel administration of both mentioned antibodies targeted at CTLA4 (Ipilimumab) and PD-1 (Nivolumab), the action of which supplement each other $[19,52,78]$. Patients after chemotherapy or chemotherapy associated with immunotherapy with rytuximab following administration of the mentioned above drugs manifested for many months a slowed down tumour development. Preliminary, positive results were also obtained in treatment of melanoma by parallel blocking of angiogenesis (using monoclonal antibody, bevacizumab) and blocking of CTLA-4 on lymphocytes [51].

Other clinical trials were conducted on patients with an advanced, already previously treated melanoma, administering them with peptide vaccine against gp100 antigen, aimed at amplification of the lymphocyte pool directed against neoplastic cells and with CTLA-4-specific antibody (Ipilimumab), or both the factors in parallel [29]. A significantly longer survival was observed in patients receiving Ipilimumab (10.0 months), including the patients receiving the combination with the peptide vaccine (10.1 months), as compared to results obtained in patients who received the peptide vaccine only (6.4 months). The peptide vaccine aimed at augmenting numbers of $\mathrm{T}$ lymphocytes capable to respond to a selected oncogen.

A still another factor, which inhibits activity of lymphocytes T, is the LAG3 factor. Gene coding for the factor (Lymphocyte activation gene-3, LAG-3) is located in the locus CD4 of T lymphocyte genome. The gene manifests expression in activated lymphocytes $\mathrm{T} \mathrm{CD}^{+}$and $\mathrm{T} \mathrm{CD} 8^{+}$. It negatively regulates (inhibits) proliferation of lymphocytes $\mathrm{T}$, inhibiting inflow of $\mathrm{Ca}^{2+}$ ions to the cell, induced 
by TCR receptor, following binding of an antigenic determinant and controlling number of T memory lymphocytes [48, 49].

Expression of LAG-3 manifests a negative correlation with effector function of specific for the tumour lymphocytes T CD8+. A co-expression of PD-1 and LAG-3 and a high expression of CTLA-4 was observed at the site of the tumour. Also, the PD- $1^{+}$and LAG- $3^{+}$cells manifested the lowest production of IFN $\gamma / \mathrm{TNF}$. Since expression of LAG-3 and PD-1 molecules develop on activated T cells. They synergestically regulate T-cells function to promote tumoral immune escape [79].

It is useful to examine the above mentioned types of control on the example of ovarian cancer (epithelial ovary cancer, EOC) [44]. Antigen NY-ESO-1 represents an antigen of testicular tumours but it is present also on cells of ovarian cancer (EOC). It represents one of the strongest till now described neoplastic antigens, inducing in some patients cell-mediated and humoral immune responses. The phenotype and functions of specific NY-ESO-1 T CD8 ${ }^{+}$in the blood, lymphocytes infiltrating the tumour (TILs) and of tumour-associated lymphocytes (TALs) were described in patients with NY-ESO- $1^{+}$tumours, manifesting humoral immunity to NY-ESO-1 or without such an immunity. The NY-ESO-1-specific lymphocytes $\mathrm{T}$ CD8+ originating from the tumor manifested an impaired effector function as compared to the blood, and on their surface they exhibited an augmented coexpression of the inhibitory molecules of LAG-3 and PD-1. Expression of LAG-3 and $\mathrm{PD}-1$ on $\mathrm{CD}^{+} \mathrm{T}$ lymphocytes increased further following activation of the APCs originating from tumour and with the cytokines IL-10, IL-6, present in the tumour exudate. Similar antigen expression and the immune profile of tumor infiltrating lymphocytes were observed in cutaneous melanoma [24].

In the course of tumour treatment, the problem arises of the accumulating population of regulatory lymphocytes $\mathrm{T}$ (Treg) [17]. It used to be assumed that expression of forkhead box P3 protein (Foxp3) represented a specific marker of Treg cells [18]. Most of commercial tests for determining the number of the cells in blood is directed at lymphocytes $\mathrm{T} \mathrm{CD} 4^{+} \mathrm{CD} 25^{+} \mathrm{Foxp} 3^{+}$. It is worth remembering that Foxp3, similarly to most of CTLA4 molecules in the cells, are localised in the cytoplasm. In mice [58], similarly to humans [43, 45] a few subtypes of Treg cells were identified. Two main subpopulations identified in humans involve the originating from thymus natural $\mathrm{T}$ reg cells (nTreg) and the arising in the periphery the induced iTreg (adaptiveTreg, aTreg) [65], but their identification is far from easy $[3,41]$.

CTLA-4 amplifies immunosupressory functions of Treg, CD4 ${ }^{+} \mathrm{CD} 25^{+}$ FoxP $3^{+}$lymphocytes. An opposite situation or deficiency of CTLA4 in an in vitro culture results in an augmented expression of CD80 and CD86 antigens on dendritic cells [32]. Also a blockade of CTLA-4 in the preclinical animal models was found to reduce numerical force of Treg lymphocytes within the tumour in a process dependent on presence of macrophages with expression of $\mathrm{Fc}$ receptors. 
A treatment of tumour-bearing mice by administration of CTLA-4-specific antibody resulted in destruction of the tumour but also in a resistance to secondary grafting with the tumour with no additional blockade of CTLA-4, or appearance of immune memory [40]. Such an appearance of immune memory we observed in our experiments with L1210 leukaemia in mice $[35,36]$.

\section{SUMMARY}

In the presented above text we have attempted to recall how tumours arise and develop. Several common stages of development were suggested for solid tumours and leukaemias/lymphomas. It was recalled that a large group of tumours affected senescent individuals, remaining under effects of repeated stress and less efficient functioning immune system. Neoplastic cells are characterised by an extensive antigenic variability, resistance to an induced or systemic apoptosis and an accumulation in tissue niches, protecting them from activity of host's defensive cells. Those protective measures involve development of a microenvironment, which shelters them from defensive activity of the host.

The generally accepted treatment of neoplasias at the first stage involves reduction of the total number of tumour cells by surgical excision, radiotherapy, chemotherapy and passive immunotherapy, using specific antibodies targeted at neoplastic cells. In parallel or in the next stage of the treatment efforts are made to amplify clones of defensive cells using appropriate vaccinations, which attract a growing attention. It seems optimum to autovaccinate the host with own, previously irradiated neoplastic cells or, alternately, using vaccination of the host with known neoplastic antigens. A subsequent stage involves elimination of the immune system blockade, developed due to activity of the tumour. Such attempts rely on elimination of the tumour-made blockade of immune system. Efforts toward this end include neutralization of tumour blockade, which inactivates tumour-targeted cytotoxicity of protective cells, mainly lymphocytes T. This may be obtained using commercially available antibodies directed against inhibitory surface receptors of lymphocytes T (CTLA-4 and PD-1). This stage requires an appropriate time and it used to provide selective results. The future of anti-neoplastic therapy is thought to be based on personalized management of the patient. Therapy of individual patients will be preceded by analysis of the tumour and of the patient's immune system by a team coordinated by a physicianoncologist, including an immunologist, genetician, molecular pathologist and a pathologist. A therapeutic management agreed in common by the specialists should provide better therapeutic effects than those currectly observed ones. 


\section{ACKNOWLEDGEMENTS}

This work was supported by the European Union structural funds and the Innovative Economy Operational Program POIG.01.01.02-00-109/09-00

\section{REFERENCES}

[1] Ahmadzadeh M, Johnson LA, Heemskerk B, Wunderlich JR, Dudley ME, White DE, Rosenberg SA. Tumor antigen-specific CD8 T cells infiltrating the tumor express high levels of PD-1 and are functionally impaired. Blood 2009; 114: 1537-1544

[2] Ansell SM. Nivolumab in the treatment of Hodgkin lymphoma. Clin Canc Res 2016; 23 (7): 1-5

[3] Baughman RP. Technical aspects of bronchoalveolar lavage: recommendations for a standard procedure. Semin.Respir Crit Care Med 2007; 28: 475-485

[4] Brandhorst G, Petrova DT, Weigand S, Eberle C, von AN, Schmitz J, Schultze FC, Raddatz D, Karaus M, Oellerich M, Walson PD. Lack of correlation between Treg quantification assays in inflammatory bowel disease patients. World J Gastroenterol. 2015; 21: 3325-3329

[5] Butts C, Socinski Ma, Mitchell Pl, Thatcher N, Havel L, Krzakowski M, Nawrocki S, Ciuleanu Te, Bosquee L, Trigo JM, Sira A, Tremblay L, Nyman J, Ramlau R, Wickart-Johansson G, Ellis P, Gladkov O, Pereira JR, Eberhardt We, Helwig C, Schroder A, Shepherd FA. Tecemotide (L-BLP25) versus placebo after chemoradiotherapy for stage III non-small-cell lung cancer (START): a randomised, double-blind, phase 3 trial. Lancet Oncol. 2014; 15: 59-68

[6] Chcialowski A, Chorostkowska-Wynimko J, Fal A, Pawlowicz R, Domagala-Kulawik J. Recommendation of the Polish Respiratory Society for bronchoalveolar lavage (BAL) sampling, processing and analysis methods. Pneumonol.Alergol.Pol. 2011; 79: 75-98

[7] Chmielowicz B, Obojski A, Barczyk A, Sozanska E, Kycler Z, Demkow U, Domagala-Kulawik J. [Methodology of induced sputum induction and processing--recommendation of Polish Respiratory Society]. Pneumonol.Alergol.Pol. 2008; 76: 378-394

[8] Dabrowska M, Grubek-Jaworska H, Domagala-Kulawik J, Bartoszewicz Z, Kondracka A, Krenke R, Nejman P, Chazan R. [Diagnostic usefulness of selected tumor markers (CA125, CEA, CYFRA 211 ) in bronchoalveolar lavage fluid in patients with non-small cell lung cancer]. Pol.Arch.Med.Wewn. 2004; 111: 659-665

[9] Domagala-KulawiK J. BAL in the diagnosis of smoking-related interstitial lung diseases: review of literature and analysis of our experience. Diagn.Cytopathol. 2008; 36: 909-915

[10] Domagala-Kulawik J. Effects of cigarette smoke on the lung and systemic immunity. J.Physiol Pharmacol. 2008; 59 Suppl 6: 19-34

[11] Domagala-KulawiK J. The role of the immune system in non-small cell lung carcinoma and potential for therapeutic intervention. Transl.Lung Cancer Res. 2015; 4: 177-190

[12] Domagala-Kulawik J, Droszcz P, Kraszewska I, Chazan R. Expression of Fas antigen in the cells from bronchoalveolar lavage fluid (BALF). Folia Histochem.Cytobiol. 2000; 38: 185-188

[13] Domagala-Kulawik J, Hoser G, Dabrowska M, Safianowska A, Chazan R. CD4+/CD25+ cel $1 \mathrm{~s}$ in systemic inflammation in COPD. Scand.J.Immunol. 2011; 73: 59-65

[14] Domagala-Kulawik J, Hoser G, Doboszynska A, Kawiak J, Droszcz W. [Phenotype of lymphocytes in bronchoalveolar lavage fluid of patients with lung fibrosis in the course of scleroderma]. Pneumonol.Alergol.Pol. 1995; 63: 382-388 
[15] Domagala-Kulawik J, Hoser G, Safianowska A, Grubek-Jaworska H, Chazan R. El evat ed TGF-beta1 concentration in bronchoalveolar lavage fluid from patients with primary lung cancer. Arch. Immunol Ther.Exp.(Warsz.) 2006; 54: 143-147

[16] Domagala-Kulawik J, Maskey-Warzecowska M. T-regulatory cells in COPD or tumour environment. Eur.Respir.J. 2009; 34: 284-286

[17] Domagala-KulawiK J, Osinska I. [Immune alterations in lung cancer - the new therapeutic approach]. Pneumonol.Alergol.Pol. 2014; 82: 286-299

[18] Domagala-Kulawik J, Osinska I, Hoser G. Mechanisms of immune response regulation in lung cancer. Transl.Lung Cancer Res. 2014; 3: 15-22

[19] Dummer CD, Carpio VN, Goncalves LF, Manfro RC, Veronese FV. FOXP3+ regulatory T cells: from suppression of rejection to induction of renal allograft tolerance. Transpl.Immunol. 2012; 26: 1-10

[20] Duraiswamy J, Kaluza KM, Freeman GJ, Coukos G. Dual blockade of PD-1 and CTLA-4 combined with tumor vaccine effectively restores T-cell rejection function in tumors. Cancer Res. 2013; 73: 3591-3603

[21] Fan F, Samuel S, Evans KW, Lu J, Xia L, Zhou Y, Sceusi E, Tozzi F, Ye XC, Mani SA, Ellis LM. Overexpression of snail induces epithelial-mesenchymal transition and a cancer stem cell-like phenotype in human colorectal cancer cells. Cancer Med. 2012; 1: 5-16

[22] Fridman Wh, Remark R, Goc J, Giraldo NA, Becht E, Hammond SA, Damotte D, Dieu-Nosjean MC, SAUtes-Fridman C. The immune microenvironment: a major player in human cancers. Int.Arch. Allergy Immunol. 2014; 164: 13-26

[23] Frydecka I, Kosmaczewska A, Bocko D, Ciszak L, Wolowiec D, Kuliczkowski K, Kochanowska I. Alterations of the expression of T-cell-related costimulatory CD28 and downregulatory CD152 (CTLA-4) molecules in patients with B-cell chronic lymphocytic leukaemia. Br.J Cancer 2004; 90: 2042-2048

[24] Galon J, Pages F, Marincola FM, Thurin M, Trinchieri G, Fox BA, Gajewski TF, Ascierto PA. The immune score as a new possible approach for the classification of cancer. J Transl.Med. 2012; 10: 1

[25] Giavina-Bianchi M, Giavina-Bianchi P, Sotto MN, Muzikansky A, Kalil J, Festa-Neto C, Duncan LM. Increased NY-ESO-1 expression and reduced infiltrating CD3+ T cells in cutaneous melanoma. J Immunol.Res. 2015; 2015: 761378

[26] Giraldo NA, Becht E, Vano Y, Sautes-Fridman C, Fridman WH. The immune response in cancer: from immunology to pathology to immunotherapy. Virchows Arch. 2015; 467: 127-135

[27] Hai J, Sakashita S, Allo G, Ludkovski O, NG C, Shepherd FA, Tsao MS. Inhibiting MDM2-p53 Interaction Suppresses Tumor Growth in Patient-Derived Non-Small Cell Lung Cancer Xenograft Models. J Thorac.Oncol. 2015; 10: 1172-1180

[28] Hamid O, Robert C, Daud A, Hodi FS, Hwu WJ, Kefford R, Wolchok JD, Hersey P, Joseph RW, Weber JS, Dronca R, Gangadhar TC, Patnaik A, Zarour H, Joshua AM, Gergich K, Elassaiss-Schaap J, Algazi A, Mateus C, Boasberg P, Tumeh PC, Chmielowski B, Ebbinghaus SW, Li XN, Kang SP, Ribas A. Safety and tumor responses with lambrolizumab (anti-PD-1) in melanoma. N.Engl.J Med. 2013; 369: 134-144

[29] Hermanowicz-Salamon J, Domagala-Kulawik J, Maskey-Warzechowska M, Chazan R. [Macrophage phenotype in induced sputum in asthma subjects]. Pneumonol.Alergol.Pol. 2006; 74: 101-105

[30] Hodi FS, O’Day SJ, McDermott DF, Weber RW, Sosman JA, Haanen JB, Gonzalez R, Robert C, Schadendorf D, Hassel JC, Akerley W, van den Eertwegh AJ, Lutzky J, Lorigan P, Vaubel JM, Linette GP, Hogg D, Ottensmeier CH, Lebbe C, Peschel C, Quirt I, Clark JI, Wolchok JD, Weber JS, Tian J, Yellin MJ, Nichol GM, Hoos A, Urba WJ. Improved survival with ipilimumab in patients with metastatic melanoma. N.Engl.J Med. 2010; 363: 711-723

[31] Hoser G, Domagala-Kulawik J, Droszcz P, Droszcz W, Kawiak J. Lymphocyte subsets differences in smokers and nonsmokers with primary lung cancer: a flow cytometry analysis of bronchoalveolar lavage fluid cells. Med.Sci.Monit. 2003; 9: BR310-BR315 
[32] Hoser G, Kawiak J, Domagala-Kulawik J, Kopinski P, Droszcz W. Flow cytometric evaluation of lymphocyte subpopulations in BALF of healthy smokers and nonsmokers. Folia Histochem.Cytobiol. 1999; 37: 25-30

[33] Hou TZ, Qureshi OS, Wang CJ, Baker J, Young SP, Walker LS, Sansom DM. A transendocytosis model of CTLA-4 function predicts its suppressive behavior on regulatory T cells. J Immunol. 2015; 194: $2148-2159$

[34] Hus I, Kawiak J, Tabarkiewicz J, Radej S, Hoser G, Bojarska-Junak A, Schmitt M, Giannopoulos K, DMOsZYNSKA A, RolinsKi J. Immunotherapy with irradiated autologous leukemic cells in patients with B-CLL in early stages. Oncol.Rep. 2008; 20: 443-451

[35] Hus I, Schmitt M, Tabarkiewicz J, Radej S, Wojas K, Bojarska-Junak A, Schmitt A, GiannopouLos K, DMoszynska A, Rolinski J. Vaccination of B-CLL patients with autologous dendritic cells can change the frequency of leukemia antigen-specific CD8+ T cells as well as CD4+CD25+FoxP3+ regulatory $\mathrm{T}$ cells toward an antileukemia response. Leukemia 2008; 22: 1007-1017

[36] KaWalec M, Jakobisiak M, Skorski T, Kawiak J. Immunogenicity of cyclophosphamide-treated leukaemia cells. Folia Biol.(Praha) 1982; 28: 334-343

[37] Kawalec M, Skorski T, Kawiak J. Successful chemoimmunotherapy of murine L1210 lymphatic leukemia with cyclophosphamide and mafosfamide-treated leukemia cells. Invest New Drugs 1988; 6: $169-172$

[38] Kawiak J, Hus I.Rolinski J, Tabarkiewicz J, Wojas K, Kosek A, Bojarska-Junak A, Kowal M, GórSKA M, DMOsZYŃSKa A Immunotherapy of B-cell Patients with autologous Irradiated Leukemic cells and BCG, Pol J Environmental Studies supl II, 2005; 14: 187-191.

[39] Kerr KM, Tsao MS, Nicholson AG, Yatabe Y, Wistuba II, Hirsch FR. Programmed Death-Ligand 1 Immunohistochemistry in Lung Cancer: In what state is this art? J Thorac.Oncol. 2015; 10: 985-989

[40] Kruger C, Greten TF, Korangy F. Immune based therapies in cancer. Histol.Histopathol. 2007; 22: 687-696

[41] Leach DR, Krummel MF, Aluison JP. Enhancement of antitumor immunity by CTLA-4 blockade. Science 1996; 271: 1734-1736

[42] Lin X, Chen M, Liu Y, Guo Z, He X, Brand D, Zheng SG. Advances in distinguishing natural from induced Foxp3(+) regulatory T cells. Int.J Clin.Exp.Pathol. 2013; 6: 116-123

[43] Liu H, Zhang T, Ye J, Li H, Huang J, Li X, Wu B, Huang X, Hou J. Tumor-infiltrating lymphocytes predict response to chemotherapy in patients with advance non-small cell lung cancer. Cancer Immunol.Immunother. 2012; 61: 1849-1856

[44] Liu J, Lluis A, Illi S, Layland L, Olek S, von ME, Schaub B. T regulatory cells in cord blood-FOXP3 demethylation as reliable quantitative marker. PLoS.One. 2010; 5: e13267

[45] Matsuzaki J, Gnjatic S, Mhanech-Fauceglia P, Beck A, Miller A, Tsuji T, Eppolito C, Qian F, Lele S, Shrikant P, Old LJ, Odunsi K. Tumor-infiltrating NY-ESO-1-specific CD8+ T cells are negatively regulated by LAG-3 and PD-1 in human ovarian cancer. Proc.Natl.Acad.Sci.U.S.A 2010; 107: 7875-7880

[46] McClymont SA, Putnam Al, Lee Mr, Esensten JH, Liu W, Hulme MA, Hoffmuller U, Baron U, Olek S, Bluestone JA, Brusko TM. Plasticity of human regulatory T cells in healthy subjects and patients with type 1 diabetes. J Immunol. 2011; 186: 3918-3926

[47] Moschella F, Torelli GF, Valentini M, Urbani F, Buccione C, Petrucci MT, Natalino F, Belardelli F, Foa R, Proietti E. Cyclophosphamide induces a type I interferon-associated sterile inflammatory response signature in cancer patients' blood cells: implications for cancer chemoimmunotherapy. Clin. Cancer Res. 2013; 19: 4249-4261

[48] Neller MA, Lopez JA, Schmidt CW. Antigens for cancer immunotherapy. Semin.Immunol. 2008; 20: 286-295

[49] Okamura T, Fujo K, Sumitomo S, Yамамото K. Roles of LAG3 and EGR2 in regulatory T cells. Ann. Rheum.Dis. 2012; 71 Suppl 2: i96-100 
[50] Okamura T, Sumitomo S, Morita K, Ifasaki Y, Inoue M, Nakachi S, Komai T, Shoda H, Miyazaki J, Fuлı K, Yамамото K. TGF-beta3-expressing CD4+CD25(-)LAG3 + regulatory T cells control humoral immune responses. Nat.Commun. 2015; 6: 6329

[51] Osinska I, Domagala-KulaWIK J. [Bronchoalveolar lavage in lung cancer-diagnostic value and assessment of the anti-cancer immune response]. Postepy Hig.Med.Dosw.(Online.) 2013; 67: 1119-1127

[52] Otт PA, Hodi FS, Buchbinder EI. Inhibition of Immune Checkpoints and Vascular Endothelial Growth Factor as Combination Therapy for Metastatic Melanoma: An Overview of Rationale, Preclinical Evidence, and Initial Clinical Data. Front Oncol. 2015; 5: 202

[53] Оtт PA, Hodi FS, Robert C. CTLA-4 and PD-1/PD-L1 blockade: new immunotherapeutic modalities with durable clinical benefit in melanoma patients. Clin.Cancer Res. 2013; 19: 5300-5309

[54] Palucka K, Banchereau J. Dendritic-cell-based therapeutic cancer vaccines. Immunity. 2013; 39: 38-48

[55] Pan Q, Li Q, Liu S, Ning N, Zhang X, Xu Y, Chang AE, Wicha MS. Concise Review: Targeting Cancer Stem Cells Using Immunologic Approaches. Stem Cells 2015; 33: 2085-2092

[56] Perez-Gracia JL, Labiano S, Rodriguez-Ruiz ME, Sanmamed MF, Melero I. Orchestrating immune check-point blockade for cancer immunotherapy in combinations. Curr.Opin.Immunol. 2014; 27: 89-97

[57] Pizzurro Ga, Tapia IJ, Sganga L, Podhajcer OL, Mordoh J, Barrio MM. Cytokine-enhanced maturation and migration to the lymph nodes of a human dying melanoma cell-loaded dendritic cell vaccine. Cancer Immunol.Immunother. 2015; 64(11): 1393-406.

[58] Postow MA, Callahan MK, Wolchoк JD. Immune Checkpoint Blockade in Cancer Therapy. J Clin. Oncol. 2015; 33: 1974-1982

[59] Putnam Al, Safinia N, Medvec A, Laszkowska M, Wray M, Mintz Ma, Trotta E, Szot Gl, Liu W, Lares A, Lee K, Laing A, Lechler Ri, Riley JL, Bluestone JA, Lombardi G, Tang Q. Cl inical grade manufacturing of human alloantigen-reactive regulatory $\mathrm{T}$ cells for use in transplantation. Am.J Transplant. 2013; 13: 3010-3020

[60] Radojcic V, Bezak KB, Skarica M, Pletneva MA, Yoshimura K, Schulick RD, Luznik L. Cyclophosphamide resets dendritic cell homeostasis and enhances antitumor immunity through effects that extend beyond regulatory T cell elimination. Cancer Immunol.Immunother. 2010; 59: 137-148

[61] RoLINSKI J, Hus I. Breaking immunotolerance of tumors: a new perspective for dendritic cell therapy. J Immunotoxicol. 2014; 11: 311-318

[62] Ruben JM, van den Ancker W, Bontkes HJ, Westers TM, Hooijberg E, Ossenkoppele GJ, de Gruijl TD, vAN DE LoosDrecht AA. Apoptotic blebs from leukemic cells as a preferred source of tumor-associated antigen for dendritic cell-based vaccines. Cancer Immunol.Immunother. 2014; 63: 335-345

[63] Sabbatini P, Tsuji T, Ferran L, Ritter E, Sedrak C, Tuballes K, Jungbluth Aa, Ritter G, Aghajanian C, Bell-McGuinn K, Hensley ML, Konner J, Tew W, Spriggs DR, Hoffman EW, Venhaus R, Pan L, Salazar AM, Diefenbach CM, Old LJ, Gnjatic S. Phase I trial of overlapping long peptides from a tumor self-antigen and poly-ICLC shows rapid induction of integrated immune response in ovarian cancer patients. Clin.Cancer Res. 2012; 18: 6497-6508

[64] Saha A, Chatterjee SK. Combination of CTL-associated antigen-4 blockade and depletion of CD25 regulatory $\mathrm{T}$ cells enhance tumour immunity of dendritic cell-based vaccine in a mouse model of colon cancer. Scand.J Immunol. 2010; 71: 70-82

[65] Salvi S, Fontana V, Boccardo S, Merlo DF, Margallo E, Laurent S, Morabito A, Rijavec E, Dal Bello MG, Mora M, Ratto GB, Grossi F, Truini M, Pistillo MP. Evaluation of CTLA-4 expression and relevance as a novel prognostic factor in patients with non-small cell lung cancer. Cancer Immunol.Immunother. 2012; 61: 1463-1472

[66] Sснmitt EG, Williams CB. Generation and function of induced regulatory T cells. Front Immunol. 2013; 4: 152

[67] Senovilla L, Vacchelli E, Galon J, Adjemian S, Eggermont A, Fridman WH, Sautes-Fridman C, Ma Y, Tartour E, Zitvogel L, Kroemer G, Galluzzi L. Trial watch: Prognostic and predictive value of the immune infiltrate in cancer. Oncoimmunology. 2012; 1: 1323-1343 
[68] Shin K, Arkenau HT, Infante JR. Cl inical impact of checkpoint inhibitors as novel cancer therapies. Drugs 2014; 74: 1993-2013

[69] Shrimali RK, Janik JE, Abu-Eid R, Mkrtichyan M, Khleif SN. Programmed death-1 \& its ligands: promising targets for cancer immunotherapy. Immunotherapy. 2015; 7: 777-792

[70] Skirecki T, Hoser G, Domagala-Kulawik J, Kawiak J. Characterization of a new small cell lung cancer (SCLC) cell line STP54 derived from a metastatic bioptate of a combined type of SCLC with Non-SCLC component. Folia Histochem.Cytobiol. 2009; 47: 111-115

[71] Skorski T, Kawalec M, Kawiak J. Mechanisms of immunological response induced in CD2F1 mice by administration of semisyngeneic L 1210 leukemia cells treated with cyclophosphamide. Immunol. Invest 1987; 16: 33-43

[72] Stadler S, Weina K, Gebhardt C, Utikal J. New therapeutic options for advanced non-resectable malignant melanoma. Adv.Med.Sci. 2015; 60: 83-88

[73] Sundar R, Soong R, Cho BC, Brahmer JR, Soo RA. Immunotherapy in the treatment of non-small cell lung cancer. Lung Cancer 2014; 85: 101-109

[74] Takiguchi Y, Sekine I, Iwasawa S, Kurimoto R, Tatsumi K. Chronic obstructive pulmonary disease as a risk factor for lung cancer. World J Clin.Oncol. 2014; 5: 660-666

[75] Taube JM, Anders RA, Young GD, Xu H, Sharma R, McMiller Tl, Chen S, Klein AP, Pardoll DM, Topalian SL, Chen L. Colocalization of inflammatory response with B7-h1 expression in human melanocytic lesions supports an adaptive resistance mechanism of immune escape. Sci.Transl.Med. 2012; 4: $127 \mathrm{ra} 37$

[76] van Montfoort N, van der Aa E, Woltman AM. Understanding MHC class I presentation of viral antigens by human dendritic cells as a basis for rational design of therapeutic vaccines. Front Immunol. 2014; 5: 182

[77] Wang C, Yu X, Wang W. A meta-analysis of efficiacy and safety of antibodies targeting PD-1/PD-L1 in treatment of advanced nonsmall cell lung cancer. Medicine 2016; 95: 52

[78] Velcheti V, Schalper Ka, Carvajal DE, Anagnostou VK, Syrigos KN, Sznol M, Herbst RS, GetTINGER SN, Chen L, RIMm DL. Programmed death ligand-1 expression in non-small cell lung cancer. Lab Invest 2014; 94: 107-116

[79] Wojas J, Pajtasz-Piasecka E. [Dendritic cell-regulatory T-cell interaction]. Postepy Hig.Med.Dosw. (Online.) 2010; 64: 167-174

[80] Wolchok JD, Kluger H, Callahan MK, Postow MA, Rizvi NA, Lesokhin AM, Segal NH, Ariyan CE, Gordon RA, Reed K, Burke MM, Caldwell A, Kronenberg SA, Agunwamba BU, Zhang X, Lowy I, Inzunza HD, Feely W, Horak CE, Hong Q, Korman AJ, Wigginton JM, Gupta A, Sznol M. Nivolumab plus ipilimumab in advanced melanoma. N.Engl.J Med. 2013; 369: 122-133

[81] Woo SR, Turnis ME, Goldberg MV, Bankoti J, Selby M, Nirschl CJ, Bettini ML, Gravano DM, Vogel P, Liu CL, Tangsombatvisit S, Grosso JF, Netto G, Smeltzer MP, Chaux A, Utz PJ, Workman CJ, Pardoll DM, Korman AJ, Drake CG, Vignali DA. Immune inhibitory molecules LAG-3 and PD-1 synergistically regulate T-cell function to promote tumoral immune escape. Cancer Res. 2012; 72: $917-927$

[82] YAo S, ZhU Y, Chen L. Advances in targeting cell surface signalling molecules for immune modulation. Nat.Rev.Drug Discov. 2013; 12: 130-146

Editor -

Jerzy Kawiak

S. Banacha Street 20/18

phone: 661850463

email: jkawiak@ibib.waw.pl 